\title{
Effect of organic farming on insect diversity
}

\author{
T. Grabovska*, V. Lavrov, O. Rozputnii, M. Grabovskyi, T. Mazur, Z. Polishchuk, N. \\ Prisjazhnjuk, L. Bogatyr
}

\author{
Bila Tserkva National Agrarian University, Bila Tserkva, Ukraine, 8/1, Soborna Sq., Bila Tserkva, Kyiv Region, \\ 09117, Ukraine
}

*Corresponding author E-mail: grabovskatatiana@gmail.com

Received: 09.08.2020. Accepted: 09.09.2020

\begin{abstract}
The paper focuses on the insect community as a "link" between ecosystem producers, secondary consumers and decomposers and the mobile and informative indicator of structure, biological stability and productivity. Consortium and other subsystems of agricultural ecosystems are mainly destroyed annually as a result of technological measures - chemical, mechanical, biological. External ecological factors, including the structure of the agrolandscape, in particular field protective forest shelter belts and ecotones between them, also have a certain influence. The research was conducted in organic agrolandscape (Kyiv region, Ukraine), comparing it with the conventional one. Insects were collected in winter wheat fields, ecotones and adjacent forest shelterbelts. The number of orders, families and individuals is greater under organic farming. The highest number of families and individuals was recorded in the forest shelterbelts adjacent to the organic landscape ( 26.3 and 111.7 , respectively). The number of individuals in organic winter wheat fields was twice as large as in conventional fields and amounted to 85.3 individuals on average; the number of families was by 1.8 times larger. Biodiversity indices (Shannon, Menhinick, Margalef, Berger-Parker, and Pielou) confirm the greater diversity of insects in the organic fields of winter wheat. The Sørensen similarity coefficient was higher in the organic fields and forest shelterbelts near the conventional fields $(C s=0.7)$, which is explained by the largest number of phytophages in these ecosystems. The share of predators and parasites that control pests in the agricultural system was highest in organic ecotones and forest shelterbelts $-26.21 \%$ and $33.12 \%$ (against 10.24 and $18.16 \%$ in conventional, respectively).
\end{abstract}

Keywords: Organic farming; Winter wheat; Insects; Biodiversity indices; Ecotone; Forest shelterbelt

\section{Introduction}

In agricultural landscapes, for reclamation purposes, systems of protective forest plantations are usually created, among which field protective forest shelterbelts (FSB) are most often bordered by agricultural lands. Together with the fields, they form a specific agroecosystem with significantly changed environmental conditions, compared to open landscapes. However, many forests were cut and transformed into the agriculture fields in Forest-Steppe regions, which has led to changes in structure and biodiversity.

Agriculture has led to a certain leveling of biotope and landscape diversity, the destruction of many ecosystems, including valuable taxa of the nature reserve fund. In addition, it has been shown that in traditional forms of activity, food production cause significant environmental threats to the environment and man, far beyond agricultural lands - due to pollution adjacent ecosystems, food chains, other flows of matter and energy, especially by pesticides. Thus, the use of pesticides and the reduction of landscape heterogeneity in agricultural areas lead to the loss of biodiversity (Gallé et al., 2018). From chemical treatments of crops, the entire entomofauna of the agricultural landscape falls under the pesticide press, which exacerbates the biodiversity crisis (Lisovyi et al., 2019).

These risks grow with the increase in chemical use and intensification of agricultural production, GMOs in crops, new effective but more toxic to the environment substances in the plant protection system, and so on. One of the promising ways to solve these problems is organic agriculture. It is based on maximum use of natural mechanisms of self-organization and self-development of ecological systems, adherence to the principles of preserving their productivity and sustainability and cycles of their development, ensuring coexistence and supporting them by greening environment and anthropogenic load within acceptable norms (limits of natural resource potential and ecological sustainability of certain ecosystems, landscape or territory). That is, production should be based on ecological processes of certain types of ecosystems (e.g. agroecosystems) and as close as possible to the nature of processing of the obtained products.

Organic farming methods are considered as an alternative that promotes biodiversity. According to Montañez \& Amarillo-Suárez (2014) and Kavitha \& Chandran (2017), species richness and abundance were significantly higher in organic crops. In addition, organic farming increases the diversity of food specialization of insects (Montañez \& Amarillo-Suárez, 2014, Kavitha \& Chandran, 2017). In particular, for Diehl et al. (2012) the presence of arable weeds in organically cultivated wheat fields promotes species richness through additional resources such as weed seeds, pollen and herbivorous prey. Marshall et al. (2003) confirmed this and indicated that many species of arable weeds support a large variety of insect species. Organic agricultural increases species richness compared with conventional methods. In organic fields, the number of predatory insects increases (Bengtsson et al., 2005). Organic farming contributes to the biological control of pests by their natural enemies. For example, in studies of Puech et al. (2014), the number of natural enemies of aphids was higher in organic fields. Krauss et al. (2011) indicated that organic fields had five times as much plant species and about twenty times as many pollinators as conventional ones. According to these authors, in some organic fields the number of pollinators was even more than a hundred times. In contrast, the number of cereal aphids was five times less in organic fields, while the abundance of predators was three times higher, and the ratio of predators to prey was twenty times 
greater in organic fields, which indicates a much greater potential for biological pest control in organic fields. The abundance, richness and diversity of species grew with increasing plant diversity and landscape complexity in spring wheat fields and an increase in the number of semi-natural habitats in the landscape (Zhao et al., 2013). Species richness was 10.5\% higher in organic than in nonorganic production fields (Schneider et al., 2014). The species evenness and heterogeneity in organic farming were generally higher in non-organic (Ovawanda et al., 2016). However, to assess the biodiversity, landscape area needs to be considered, as, for example, a higher edge area can lead to higher species richness (Batáry et al., 2013), and landscape composition affects habitat fragmentation (Holzschuh et al., 2010). Thus, the aim of the study was to evaluate the impact of spatial and temporal organic landscape structure on the insect diversity in winter wheat fields, protected with forest shelterbelts.

\section{Materials and Methods}

The present study was conducted in Skvyra Research Station for Organic Production of Institute of Agroecology and Environmental Management of National Academy of Science (Kyiv region, Ukraine) in 2017-2019. The territory of Skvyra district is characterized by a moderately warm and moderately humid climate. The sum of active (above $5^{\circ} \mathrm{C}$ ) temperatures is $2616^{\circ} \mathrm{C}$. Weather conditions over the years of research were characterized by an increase in temperature on $14.2^{\circ} \mathrm{C}$ and sometimes a lack of precipitation by 38.2 $\mathrm{mm}$ or their excess by $70.4 \mathrm{~mm}$ per month. The soil was typical medium-loamy black, the humus content in the arable layer of the soil was 3.64\%. The sowing area of winter wheat was 5.4-6.12 ha, depending on the year of the study.

The diversity of insects in winter wheat fields was studied by use of organic technology (without use of pesticides, chemical plant protection products and mineral fertilizers). The territory with the conventional technology of growing winter wheat (with the applying Basagran and Fusilade Forte) was taken as a control.

The composition of the main tree species in the FSB of organic landscape: Populus nigra L., P. laurifolia Ledeb, Quercus robur L., Fraxinus excelsior L., F. pennsylvanica Marshall, Juglans regia L., J. cinerea L., Ulmus laevis Pall., U. minor Mill. Robinia pseudoacacia L., Cerasus avium (L.) Moench and others. Betula pendula Roth, F. excelsior, Picea abies (L.) H. Karst., Malus domestica Borkh., and J. cinerea grow in the FSB adjacent to the winter wheat field with conventional technology.

Insects were collected in winter wheat crops, in ecotones (field edges) and in adjacent forest shelter belts by the standard method of mowing with an entomological net (100 waves). The study was conducted at the stage of development of winter wheat $\mathrm{BBCH} 85$ by the international scale.

Indices were used to assess diversity (Magurran 1998, Pesenko 1982):

$$
\begin{aligned}
& \text { Shannon: } H^{\prime}=-\sum\left(P_{i} \times \ln P_{i}\right), \\
& \text { Menhinick: } D_{M n}=S / \sqrt{N}, \\
& \text { Margalef: } D_{M g}=(S-1) / \ln N, \\
& \text { Berger-Parker: } D=N_{\max } / N^{\prime}, \\
& \text { Pielou: } E_{p}=H^{\prime} / \ln S, \\
& \text { Sørensen: } C_{s}=2 j /(a+b),
\end{aligned}
$$

where $\mathrm{Pi}=\mathrm{Ni} / \mathrm{N}$ is the relative abundance of families; $\mathrm{S}$ - number of registered families; $\mathrm{N}$ - the total number of all families; $\mathrm{Ni}-$ the number of each family; Nmax - the number of the largest family; $a$ is the number of families present in the first list, $b$ is the number of families present in the second list, $j$ is the number of families common to both lists.

\section{Results and Discussion}

We recorded the following insect families in the organic ecosystems: Anthocoridae, Aphididae, Aphrophoridae, Cercopidae, Cicadellidae, Coreidae, Lygaeidae, Miridae, Pentatomidae, Psyllidae, Rhopalidae, Scutelleridae (Hemiptera); Anthicidae, Apionidae, Cantharidae, Carabidae, Chrysomelidae, Cleridae, Coccinellidae, Curculionidae, Latridiidae, Melyridae, Mordellidae, Nitidulidae, Scarabaeidae, Tenebrionidae (Coleoptera); Chrysopidae (Neuroptera); Geometridae, Nymphalidae, Plutellidae (Lepidoptera); Agromyzidae, Anthomyiidae, Asilidae, Chloropidae, Drosophilidae, Stratiomyidae, Syrphidae, Tephritidae (Diptera); Aphelinidae, Braconidae, Chalcididae, Colletidae, Crabronidae, Formicidae, Halictidae, Megachilidae, Proctotrupidae, Pteromalidae, Torymidae (Hymenoptera); and Tettigoniidae (Orthoptera).

Insect families with the cultivation of winter wheat by conventional technology in 2017-2019 were Anthocoridae, Aphididae, Cercopidae, Cicadellidae, Coreidae, Lygaeidae, Miridae, Nabidae, Pentatomidae, Rhopalidae, Scutelleridae, Tingidae (Hemiptera); Apionidae, Cantharidae, Carabidae, Chrysomelidae, Coccinellidae, Curculionidae, Latridiidae, Melyridae, Mordellidae, Nitidulidae (Coleoptera); Chrysopidae (Neuroptera); Nymphalidae, Plutellidae, Tortricidae (Lepidoptera); Agromyzidae, Anthomyiidae, Asilidae, Chloropidae, Syrphidae, Tachinidae, Tephritidae (Diptera); Andrenidae, Aphelinidae, Braconidae, Cephidae, Chalcididae, Crabronidae, Formicidae, Halictidae, Megachilidae, Proctotrupidae (Hymenoptera); Acrididae, Gryllidae, and Tettigoniidae (Orthoptera). Families of identified insects that dominated in ecosystems and accounted for more than $20 \%$ of the predominance are Aphididae, Cicadellidae, Miridae (Hemiptera), Cantharidae, Chrysomelidae (Coleoptera), Agromyzidae (Diptera), Formicidae, and Proctotrupo. The order Hemiptera ( 50.3 individuals) and Coleoptera (40.3 individuals) dominated the most by the years of research in the organic agrolandscape (Table 1). Ecosystems with conventional wheat cultivation were the least numerous, dominated by Hemiptera (32.0 individuals) and Hymenoptera (23.3 individuals).

The largest number of families and individuals was recorded in the FSB adjacent to organic landscape (26.3 and 111.7 , respectively), in the FSB of the conventional agrolandscape, these indicators were 74.7 and 23.0 (Figure 1). In ecotones, the number of insects was 18.0 and 43.0 on average for 2017-2019. The number of individuals in organic wheat fields was twice as large as in conventional fields and was 85.3 individuals on average; the number of families was 1.8 times more. 
Table 1. Taxonomic distribution of insects in agricultural landscapes (mean of 2017-2019).

\begin{tabular}{lllllll}
\hline Order & \multicolumn{2}{l}{ Organic } & \multicolumn{5}{c}{ Conventional } \\
& field & ecotone & FSB & field & ecotone & FSB \\
Hemiptera & $50.3^{*}$ & 3.7 & 30.3 & 9.7 & 6.3 & 32.0 \\
Coleoptera & 9.0 & 3.0 & 40.3 & 4.0 & 6.7 & 9.7 \\
Neuroptera & 1.0 & 1.3 & 1.0 & - & - & - \\
Lepidoptera & 3.0 & 1.0 & 1.5 & - & 1.0 & 2.5 \\
Diptera & 11.3 & 5.3 & 11.3 & 13.0 & 13.3 & 8.0 \\
Hymenoptera & 13.0 & 5.3 & 23.7 & 16.3 & 11.3 & 23.3 \\
Orthoptera & - & - & 7.0 & - & 2.0 & - \\
\hline
\end{tabular}

* Factor $A$ - order, factor $B-$ ecosystem, SD-05 A = 3,1; SD-05 B = 2,2; SD-05 AB= 3,7.

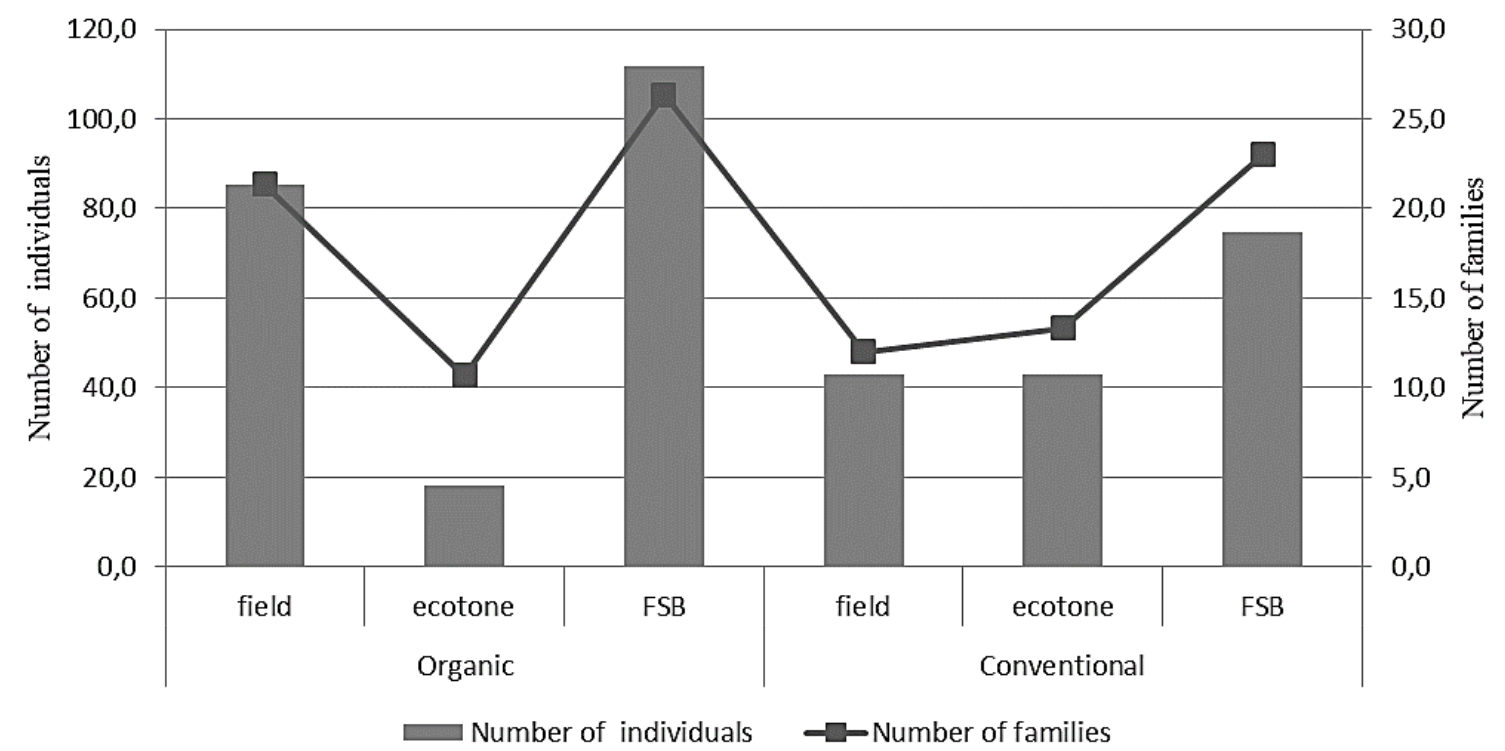

Figure 1. Number of insect families and individuals in agricultural landscapes, average for 2017-2019.

The field ecosystem with organic winter wheat had the largest share of phytophages (76\%), in conventional winter wheat - $51 \%$ (Figures 2 and 3). However, in the ecotones and forest shelter belts of the organic landscape, insects that feed on plants were less - 43 and $49 \%$, than in the conventional - 57 and $61 \%$. This can be explained by the fact that phytophages migrate from conventional fields to adjacent ecosystems - ecotones and FSB.

The highest percentage of pollinators was observed in the organic ecotone (10\%). The share of predators and parasites that help control pests in the agricultural system was the highest in organic ecotones and FSB $-26,21 \%$ and $33,12 \%$, respectively. That is, the biological control of phytophages depends on the ecosystems adjacent to the field.

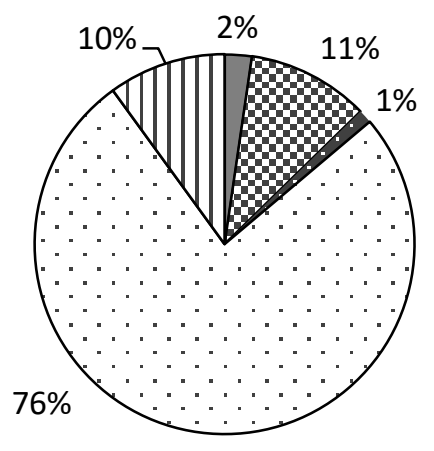

a

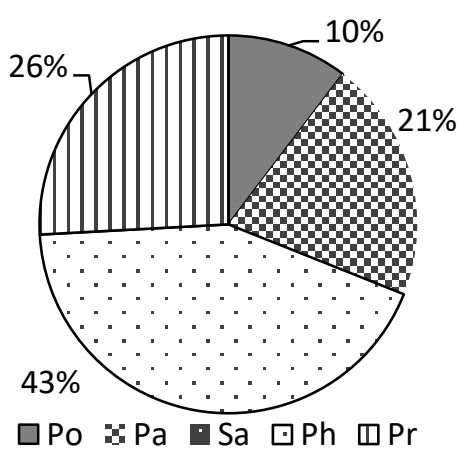

b

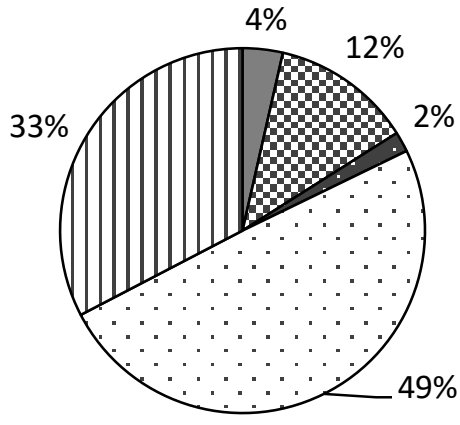

C

Figure 2. Distribution of insects by feed specialization in organic landscape: $\mathrm{Pr}$ - predators, Sa - saprophages, Ph - phytophages, $\mathrm{Pa}$ - parasites, Po - pollinophages ( $\mathrm{a}$ - winter wheat field, b - ecotone, c - FSB), average for 2017-2019. 


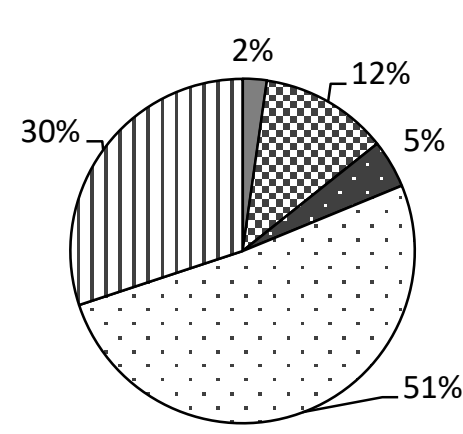

a

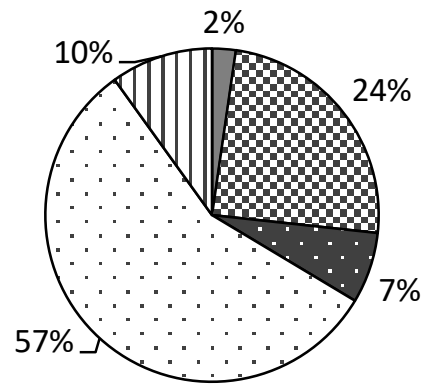

Po $\triangle \mathrm{Pa} \square \mathrm{Sa} \square \mathrm{Ph} \square \mathrm{Pr}$

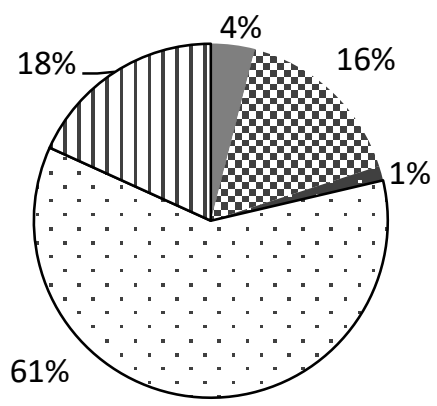

Figure 3. Distribution of insects by trophical specialization in conventional landscape: Pr - predators, Sa - saprophages, Ph phytophages, Pa - parasites, Po - pollinophages ( $\mathrm{a}$ - winter wheat field, b - ecotone, c - FSB), average for 2017-2019.

The value of the Shannon index did not differ under conventional and organic technologies, but varied depending on the ecosystem. The greatest diversity of insects was in FSB (the index was 2.84 and 2.74 according to organic and conventional technology) (Table 2). The diversity of insects, determined by the Menhinick index, was greater in the organic field of winter wheat $\left(D_{M n}=2.60\right.$ for organic fields, $D_{M n}=2.08$ for conventional). The Margalef index confirmed this, it was 4.82 in the organic fields of winter wheat and 3.14 in the conventional fields. The values of the last two indices were statistically equal in the ecotones and forest belts, regardless of crop technology.

The highest values of the Berger-Parker index were in winter wheat fields, as there was a dominance of some families of insect pests ( 0.34 for organic and 0.38 for conventional technology), as evidenced by the evenness index, the lowest values of the Pielou index were in field ecosystems ( 0.77 and 0.76 under organic and conventional technologies respectively).

Table 2. Diversity indices of insect communities in the agriculture ecosystem, average for 2017-2019.

\begin{tabular}{|c|c|c|c|c|c|c|}
\hline Index & $\begin{array}{l}\text { Organic } \\
\text { field }\end{array}$ & ecotone & FSB & $\begin{array}{l}\text { Conventional } \\
\text { field }\end{array}$ & ecotone & FSB \\
\hline \multicolumn{7}{|c|}{ Diversity indices } \\
\hline Shannon & $2.30 \pm 0.23$ & $2.24 \pm 0.14$ & $2.84 \pm 0.19$ & $1.89 \pm 0.21$ & $2.22 \pm 0.10$ & $2.74 \pm 0.14$ \\
\hline & $2.60 \pm$ & & & & & \\
\hline Margalef & $4.82 \pm 0.34$ & $3.34 \pm 0.48$ & $5.49 \pm 0.51$ & $3.14 \pm 0.28$ & $3.38 \pm 0.32$ & $5.15 \pm 0.50$ \\
\hline \multicolumn{7}{|c|}{ Dominance index } \\
\hline $\begin{array}{l}\text { Berger-Parker } \\
\text { Evenness index }\end{array}$ & $0.34 \pm 0.08$ & $0.18 \pm 0.03$ & $0.21 \pm 0.05$ & $0.38 \pm 0.06$ & $0.28 \pm 0.04$ & $0.21 \pm 0.05$ \\
\hline Pielou & $0.77 \pm 0.16$ & $0.95 \pm 0.01$ & $0.88 \pm 0.04$ & $0.76 \pm 0.10$ & $0.86 \pm 0.04$ & $0.87 \pm 0.03$ \\
\hline
\end{tabular}

The largest number of families (Table 3) common to both ecosystems was observed in forest belts (16.0), but the Sørensen similarity index, which takes into account the total number of families, was high in the organic field and forest belt adjacent to the conventional field $\left(C_{s}=0.7\right)$. This can be explained by the fact that in these ecosystems the largest number of phytophages, which is confirmed by Figures 2 and 3.

Table 3. Sørensen similarity coefficient for insect communities in organic and conventional agricultural ecosystems, average for 2017-2019

\begin{tabular}{|c|c|c|c|c|c|c|}
\hline \multirow[b]{2}{*}{ Coefficient } & \multicolumn{3}{|c|}{ Organic } & \multicolumn{3}{|c|}{ Conventional } \\
\hline & field & ecotone & FSB & field & ecotone & FSB \\
\hline \multicolumn{7}{|l|}{ Organic: } \\
\hline field & - & 0.5 & 0.5 & 0.6 & 0.5 & 0.7 \\
\hline ecotone & 8.0 & - & 0.4 & 0.4 & 0.4 & 0.4 \\
\hline FSB & 11.0 & 7.7 & - & 0.6 & 0.5 & 0.5 \\
\hline \multicolumn{7}{|l|}{ Conventional: } \\
\hline field & 9.7 & 5.3 & 11.0 & - & 0.6 & 0.5 \\
\hline ecotone & 9.3 & 5.3 & 10.7 & 7.3 & - & 0.5 \\
\hline FSB & 15.0 & 7.0 & 16.0 & 8.7 & 9.7 & - \\
\hline
\end{tabular}

The upper right corner is the Sorensen index; the lower left corner is the number of families

In the organic agrolandscape we found Carpocoris fuscispinus Boheman, 1851, Dolycoris baccarum L., 1758 (Pentatomidae), Opilo pallidus Olivier, 1795 (Cleridae), Coreus marginatus L., 1758 (Coreidae), Eurygaster integriceps Puton, 1881 (Scutelleridae), Trigonotylus sp. (Miridae) (Hemiptera order), Anisoplia austriaca Herbst, 1783 (Scarabaeidae), Ceutorhynchus obstrictus Marsham, 1802 (Curculionidae), Chrysomela populi L., 1758, Phyllotreta sp., Phyllotreta vittula Redtenbacher, 1849 (Chrysomelidae), Coccinella septempunctata L., 1758, Harmonia axyridis Pallas, 1773, Propylea quatuordecimpunctata L., 1758 (Coccinellidae), 
Notoxus monoceros L., 1761 (Anthicidae), Rhagonycha fulva Scopoli, 1763 (Cantharidae) (Coleoptera order), Syrphus sp. (Syrphidae) (Diptera order), Philantus sp. (Crabronidae) (Hymenoptera order); in the ecotones - Eurygaster integriceps (Scutelleridae), Lygus sp. (Miridae) (Hemiptera order), Malachius geniculatus Germar, 1824 (Malachiidae) (Coleoptera order), Chrysopa sp. (Chrysopidae) (Neuroptera order), Cerceris sp. (Crabronidae) (Hymenoptera order); in the FSB - Adelphocoris lineatus Goeze, 1778, Deraeocoris sp., Lygus sp. (родина Miridae), Palomena prasina L., 1761 (Pentatomidae), Stictopleurus sp. (родина Rhopalidae) (Hemiptera order), Adonia variegate Goeze, 1777, Baris artemisiae Panzer, 1794, Thea vigintiduoctopunctata L., 1758, Coccinella septempunctata, Scymnus frontalis Fabricius, 1787, Harmonia axyridis, Propylea quatuordecimpunctata (Coccinellidae), Bruchus pisorum L., 1758, Cryptocephalus sp., Oulema melanopus L., 1758, Chaetocnema sp., Phyllotreta atra Fabricius, 1775, Phyllotreta sp., Phyllotreta vittula, Longitarsus sp. (Chrysomelidae), Cantharis sp. (Cantharidae), Cordylepherus viridis Fabricius, 1787, Malachius geniculatus (Malachiidae), Eusomus ovulum Germar, 1824, Sitona lineatus L., 1758 (Curculionidae), Hylaeus sp. (Colletidae), Lagria sp. (Tenebrionidae), Meligethes aeneus Fabricius, 1775 (Nitidulidae), Mordellistena sp. (Mordellidae), Paratynus femoralis Erichson, 1840, Paratynus sp. (Melyridae), Taeniapion urticarium Herbst, 1784 (Apionidae) (Coleoptera order), Andrena $s p$. (Andrenidae) (Hymenoptera order).

In ecosystems, where pesticides were used in the fields, we registered Aelia sp. (Pentatomidae), Eurygaster integriceps, Eurygaster maura L., 1758 (родина Scutelleridae) (Hemiptera order), Ceutorhynchus obstrictus, Larinus carlinae Olivier, 1807, Sitona lineatus L., 1758 (Curculionidae), Longitarsus sp., Phyllotreta sp. (Chrysomelidae), Nemonyx lepturoides Fabricius, 1801 (Nemonychidae) (Coleoptera order); in the ecotones - Eurydema oleracea L., 1758 (Pentatomidae), Eurygaster integriceps (Scutelleridae), Nabis sp. (Nabidae), Stictopleurus sp. (Rhopalidae) (Hemiptera order), Malachius geniculatus (Malachiidae), Notoxus monoceros (Anthicidae), Phyllotreta atra, Phyllotreta vittula (Chrysomelidae), Scymnus frontalis (Coccinellidae) (Coleoptera order), Oecanthus pellucens Scopoli, 1763 (Gryllidae) (Orthoptera order); in the FSB - Adelphocoris lineatus, Lygus sp., Notostira sp. (Miridae), Coreus marginatus (Coreidae), Eurydema oleracea (Pentatomidae), Eurygaster maura (Scutelleridae), Himacerus apterus Fabricius, 1798 (Nabidae), Orius sp. (Anthocoridae), Rhopalus subrufus Gmelin, 1790 (Rhopalidae) (Hemiptera order), Baris artemisiae, Propylea quatuordecimpunctata (Coccinellidae), Cryptocephalus sp., Phyllotreta sp., Phyllotreta vittula (Chrysomelidae), Mordellistena sp. (Mordellidae), Nemonyx lepturoides (Nemonychidae), Paradromius linearis Olivier, 1795 (Carabidae), Taeniapion urticarium (Apionidae) (Coleoptera order), Cydia nigricana Fabricius, 1794, Eucosma sp. (Tortricidae) (Lepidoptera order), Andrena sp. (Andrenidae) (Hymenoptera order), Leptophyes albovittata Kollar, 1833 (Tettigoniidae) (Orthoptera order).

Opilo pallidus, which was found in the organic fields of winter wheat, was not typical for the Forest-Steppe zone of Ukraine. It is usually found in the Steppe. Such migration indicates the gradual climate change and warming in the northern regions.

\section{Conclusion}

Organic agroecosystems differ from conventional ones by greater insect diversity, as indicated by the relevant indices, as well as the diversity of taxa and the number of individuals. The largest number of phytophages was recorded in the organic fields of winter wheat, but in organic ecotones and adjacent protective forest shelter belts, compared to the conventional ones, there was a larger share of predators and parasites. The similarity of organic field ecosystems and conventional forest belt by the Sørensen coefficient indicates the migration of phytophages from conventional fields to adjacent areas.

\section{Aknowlegments}

The authors are grateful to Dr. Sci. Prof. Alexander Putchkov, Chief of Lab. of Foundation Zoological Collections, Institute of Zoology National Academy of Science of Ukraine, for his assistance with insects' identification.

\section{References}

Batáry, P., Sutcliffe, L., Dormann. C.F., Tscharntke, T. (2013) Organic Farming Favours Insect-Pollinated over NonInsect Pollinated Forbs in Meadows and Wheat Fields. PlosOne, 8(1), e54818.

Bengtsson, J,. Ahnström, J., Weibull, A.-C. (2005) The effects of organic agriculture on biodiversity and abundance: a meta-analysis. Journal of Applied Ecology, 42, 261-269.

Diehl, E., Wolters, V. \& Birkhofer, K. (2012) Arable weeds in organically managed wheat fields foster carabid beetles by resource- and structure-mediated effects. Arthropod-Plant Interactions 6, 75-82.

Gallé, R., Happe, A.-K., Baillod, A.B., Tscharntke, T., Batáry, P. (2018) Landscape configuration, organic management, and within-field position drive functional diversity of spiders and carabids. J Appl Ecol. 2019, 56: 63-72.

Holzschuh, A., Steffan-Dewenter, I., Tscharntke, T. (2010) How do landscape composition and configuration, organic farming and fallow strips affect the diversity of bees, wasps and their parasitoids? Journal of Animal Ecology. 79, Issue 2, 305-509.

Kavitha, V., Chandran, K. (2017) Organic farming in conserving bio diversity in India-A review. Agricultural Reviews, 38, Issue: 4, 316- 320.

Krauss, J.,. Gallenberger, I., Steffan-Dewenter, I. (2011) Decreased Functional Diversity and Biological Pest Control in Conventional Compared to Organic Crop Fields. PLOS ONE 6(5): e19502.

Lisovyi, M.M.,. Mukhammed, M.Z, Chaika, V.M. (2019) Otsiniuvannia riznomanittia komakh ahroekosystem [Assessment of insect diversity of agroecosystems]. Agroecological journal, No. 3, 100-104.

Magurran, A.E. (1998) Ecological diversity and its measurement. Princeton University Press, New Jersey (Princeton).

Marshall, E.J.P., Brown, V.K., Boatman, N.D., Lutman, P.J.W., Squire, G.R. and Ward, L.K. (2003), The role of weeds in supporting biological diversity within crop fields*. Weed Research, 43, 77-89.

Montañez, M.N., Amarillo-Suárez, Á. (2014) Impact of organic crops on the diversity of insects: a review of recent research. Revista Colombiana de Entomología [online], 40, n.2, 131-142.

Ovawanda, E.A., Witjaksono, W., Trisyono Y.A. (2016) Insect Biodiversity in Organic and Non-Organic Rice Ecosystem in The District of Bantul. Jurnal Perlindungan Tanaman Indonesia, 20, No 1.

Pesenko. Yu.A. (1982) Printsipy i metody kolichestvennogo analiza $v$ faunisticheskikh issledovaniyakh [Principles and methods of quantitative analysis in faunal studies]. Moscow, Russia: Science. 287 p. (in Russian). 
Puech, C., Baudry, J., Joannon, A., Poggi, S., Aviron S. (2014) Organic vs. conventional farming dichotomy: Does it make sense for natural enemies? Agriculture, Ecosystems \& Environment, 194, 48-57.

Schneider, M., Lüscher, G., Jeanneret, P. et al. (2014) Gains to species diversity in organically farmed fields are not propagated at the farm level. Nat Commun, $5,4151$.

Zhao, Z., Liu, J.-H., He, D.-H., Guan, X. Liu, W.-H. (2013) Species composition and diversity of parasitoids and hyperparasitoids in different wheat agro-farming systems. Journal of Insect Science, 13, Issue 1, 162.

\section{Citation:}

Grabovska, T., Lavrov, V., Rozputnii, O., Grabovskyi, M., Mazur, T., Polishchuk, Z., Prisjazhnjuk, N., Bogatyr, L. (2020). Effect of organic farming on insect diversity. Ukrainian Journal of Ecology, 10(4), 96-101. 